ISSN: $1979-4940$

E-ISSN : 2477-0124
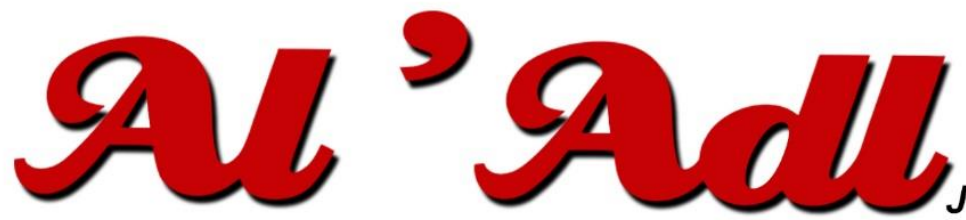

Editorial Office: Faculty of Law, Islamic University Of Kalimantan,

Jalan Adhyaksa No. 2 Kayutangi Banjarmasin, Kalimantan Selatan, Indonesia (70123)

Email: al_adl@uniska-bjm.ac.id

Web: http://ojs.uniska-bjm.ac.id

\title{
Eksistensi Persidangan Online Ditengah Pandemi Covid-19 Dalam Perkara Pidana di Indonesia
}

\author{
${ }^{[1]}$ Hanafi* ${ }^{[2]}$ Muhammad Syahrial Fitri ${ }^{[3]}$ Fathan Ansori \\ Universitas Islam Kalimantan Muhammad Arsyad Al-Banjari \\ Jl. Adhyaksa No.2 Kayutangi, Banjarmasin \\ E-mail: ${ }^{(1)}$ hanafiramsi@gmail.com; \\ (3) iyal_888@yahoo.co.id ; \\ (3) ansorifathan7@ gmail.com
}

\author{
Submitted \\ : 31 Maret 2021 \\ Revised \\ : 29 April 2021 \\ Accepted \\ : 01 Mei 2021 \\ Published \\ : 21 Mei 2021 \\ *Corespondent Author \\ (C) Licence by CC BY-NC-SA
}

\begin{abstract}
Following the background, the problems in this study are, first, the mechanism for implementing procedural law in E-Court for criminal cases in Indonesia, secondly how E-Court accommodates the process of proof in criminal cases in Indonesia. The method used in this research is pure legal research, which refers to and bases on legal norms and principles, applicable laws and regulations, legal theories and doctrines, jurisprudence, and other literature that are relevant to the topic. The results of this study are, firstly, the mechanism for implementing E-Court procedural law is regulated in the Supreme Court Regulation 4/2020 on the Administration and Trial of Criminal Cases in Electronic Courts provides 2 (two) alternatives for conducting trials in criminal cases, namely Normal Courts and Electronic Courts. Such matters are not previously regulated in the Criminal Procedure Code or other procedural regulations. Second, concerning the process of proofing evidence in criminal cases in E-Court still follows the provisions of the normal criminal procedure law and has the same value or power of evidence as normal trials.
\end{abstract}

Keywords: Covid-19 Pandemic; Criminal Cases; Electronic Courts.

\section{Abstrak}

Sesuai dengan latar belakang masalah, maka rumusan masalah yang peneliti angkat dalam penelitian ini adalah, pertama bagimana mekanisme penerapan hukum acara pada persidangan online dalam perkara pidana di Indonesia, kedua bagaimana persidangan online mengakomodir proses pembuktian dalam perkara pidana di Indonesia. Metode penelitian yang digunakan dalam penelitian ini adalah dengan menggunakan jenis penelitian hukum normatif, yaitu penelitian yang dalam pengkajiannya mengacu dan mendasarkan pada norma-norma dan kaidah-kaidah hukum, peraturan perundang-undangan yang berlaku, teori-teori dan doktrin hukum, yurisprudensi, dan bahan-bahan kepustakaan lainnya yang relevan dengan topik penelitian yang dibahas. Hasil dari penelitian ini adalah, pertama mekanisme penerapan hukum acara pada persidangan online dalam perkara pidana sebagaimana diatur dalam Peraturan Mahkamah Agung Nomor 4 tahun 2020 tentang Adminstrasi dan Persidangan Perkara Pidana di Pengadilan Secara Elektronik memberikan 2 (dua) alternatif untuk melakukan 
persidangan dalam perkara pidana, yaitu secara offline dan secara online. Hal demikian memang tidak diatur sebelumnya di dalam Kitab Undang-Undang Hukum Acara Pidana (KUHAP) atau peraturan hukum lainnya. Kedua, berkaitan dengan proses pembuktian dalam perkara pidana pada persidangan online pada dasarnya tetap mengikuti ketentuan dalam hukum acara pidana dan memiliki nilai atau kekuatan pembuktian yang sama dengan sidang yang dilakukan secara offline.

Kata kunci: Pandemi Covid-19; Perkara Pidana; Persidangan Online.

\section{PENDAHULUAN}

Sejak merebaknya wabah Corona Virus Disease-2019 (Covid-19) pada awal tahun 2020 di Indonesia seolah telah membuat lumpuhnya kegiatan masyarakat di berbagai sektor, mulai dari aspek pendidikan, sosial, ekonomi, bahkan hukum sekalipun. Pandemi Covid-19 membuat kegiatan apapun serba terbatasi, karena pemerintah menerapkan standar tinggi protokol kesehatan seperti memakai masker, social / physical distancing atau menjaga jarak, dan tidak berkerumun demi menjaga keselamatan masyarakat dan meminimalisir penyebaran Covid-19 ini.

Di bidang hukum sendiri, penyebaran Covid-19 yang masif terjadi mempengaruhi berjalannya proses penegakan hukum. Salah satunya adalah aktivitas persidangan, yang tak luput dari timbulnya dilema akibat pandemi Covid-19. Aktivitas persidangan yang paling terdampak permasalahannya akibat pandemi Covid-19, yaitu pada persidangan perkara pidana.

Dengan alasan masa tahanan yang terbatas, menjadi dasar bagi Mahkamah Agung (MA) untuk menetapkan persidangan online dengan berdasar pada Peraturan Mahkamah Agung Nomor 1 tahun 2019 tentang Tata Cara Persidangan Secara Elektronik. Bahkan Mahkamah Agung (MA) telah mengeluarkan Surat Edaran Nomor 1 Tahun 2020 tentang Pedoman Pelaksanaan Tugas Selama Masa Pencegahan Penyebaran Corona Virus Disease (Covid-19) di Lingkungan Mahkamah Agung dan Badan Peradilan yang Berada di Bawahnya (SEMA No. 1 Tahun 2020). SEMA No. 1 Tahun 2020 kemudian diubah dengan SEMA No. 2 Tahun 2020 dan diubah lagi dengan SEMA No. 3 Tahun 2020. Peraturan tersebut mengatur hakim dan aparatur peradilan dapat menjalankan tugas kedinasan dengan bekerja di rumah atau tempat tinggalnya (work from home/WFH). WFH tersebut termasuk pelaksanaan agenda persidangan pemeriksaan perkara yang dilakukan secara elektronik melalui teleconference.

Kebijakan untuk melakukan persidangan secara elektronik diperkuat dengan adanya sebuah MoU (Memorandum of Understanding) kesepakatan antara pihak Mahkamah Agung, 
Kejaksaan Agung Republik Indonesia dan Kementerian Hukum dan HAM dalam hal ini Direktorat Jenderal Pemasyarakatan disahkan tanggal 13 April 2020 No. 402/DJU/KM.01.1/4/2020; KEP-17/E/Ejp/04/2020; PAS-08.HH.05.05.Tahun 2020 tentang Pelaksanaan Persidangan Melalui Teleconference. MoU tersebut terkait kesepakatan pelaksanaan persidangan selama masa pandemi Covid-19 yang akan dilaksanakan sampai dengan berakhirnya wabah Covid-19 di Indonesia.

Dalam MoU itu ditetapkan salah satunya kesepakatan untuk menjalankan persidangan perkara pidana secara online. Lebih jelasnya hal tersebut, juga sesuai instruksi Jaksa Agung yaitu untuk mencegah penyebaran dan penularan Covid 19 agar perkara pidana disidangkan secara online. Instruksi tersebut tertuang dalam Surat Edaran Jaksa Agung (SEJA) Nomor B049/A/SUJA/03/2020 tanggal 27 Maret 2020 tentang Optimalisasi Pelaksanaan Tugas, Fungsi dan Kewenangan Kejaksaan di tengah pandemi Covid 19.

Dengan adanya SEMA No. 1 Tahun 2020 beserta perubahannya dan MoU antara MA, Kejaksaan Agung, dan Kementerian Hukum dan HAM yang menyepakati untuk menyelenggarakan persidangan secara elektronik, maka persidangan secara elektronik telah banyak dilakukan pada masa pandemi Covid-19. Kejaksaan Agung mencatat, sejak 30 Maret hingga 6 Juli 2020 ada sebanyak 176.912 perkara tindak pidana umum yang telah menjalani persidangan secara elektronik. Sedangkan KPK tercatat telah menggelar persidangan secara elektronik sebanyak 40 perkara. ${ }^{1}$

Pelaksanaan persidangan virtual melalui sarana teleconference dipandang perlu seiring dengan kebijakan protokol kesehatan yang dikeluarkan oleh pemerintah tentang social distancing dan phisyical distancing, guna menekan laju perkembangan Pandemi Covid-19. Merujuk kepada ketentuan sistem peradilan pidana di Indonesia, persidangan online ini dapat dikategorikan menjadi suatu bentuk terobosan hukum (rules breaking). Peraturan Mahkamah Agung ini adalah peraturan untuk menciptakan kepastian hukum, keadilan bermartabat bagi terdakwa, jaksa, advokat, dan hakim untuk menyelesaikan perkara pidana. ${ }^{2}$ Hal ini ditujukan agar tidak ada terjadi penyebaran Covid-19 di Lembaga Pemasyarakatan, rumah tahanan dan juga untuk menekan angka penyebaran di Pengadilan.

1 Achmad Nasrudin Yahya, 09 Juli 2020, "Menyoal Payung Hukum Persidangan Online”, Kompas.com, https://nasional.kompas.com/read/2020/07/09/07160431, diakses tanggal 09 Juli 2020.

${ }^{2}$ Rizky P.Karo, Peradilan Tindak Pidana Melalui Media Elektronik (Sidang Pidana Online) Saat Pandemi Covid-19 Perspektif Teori Keadilan Bermartabat: Tantangan Dan Rekomendasi, Jurnal Spektrum Hukum, Volume 17, Nomor 2, 2020, hlm. 45. 
Sebagai tindak lanjut dari MoU tersebut Mahkamah Agung (MA) telah menerbitkan Peraturan Mahkamah Agung Nomor 4 Tahun 2020 tentang Administrasi dan Persidangan Perkara Pidana di Pengadilan Secara Elektronik (Perma Sidang Pidana Online). Perma ini mengatur tata cara pelaksanaan persidangan perkara pidana baik perkara pidana dalam lingkup peradilan umum, militer, maupun jinayat secara daring (online).

Upaya melaksanakan persidangan online dimasa pandemi Covid-19 dianggap sebagai langkah progresif dalam memecahkan permasalahan stagnasi perkara akibat penyebaran Covid-19. Hal ini perlu dilakukan, karena apabila persidangan tetap dilaksanakan dengan pola langsung sebagaimana biasa, maka beresiko terdampak virus Covid-19, sedang bila persidangan ditunda, maka mengakibatkan kerugian bagi para terdakwa, karena nasib dan status yang belum jelas dari para hakim. ${ }^{3}$

Namun demikian bukan berati persidangan online yang digelar ini bukan tanpa masalah dan catatan. Pertama persidangan perkara pidana yang dilakukan secara online ini tidak diatur dalam ketentuan Kitab Undang-Undang Hukum Acara Pidana (KUHAP). Sehingga akan menimbulkan disharmonisasi hukum dan pada praktiknya terkesan tergesagesa atau dipaksakan dan mengurangi bahkan mengesamping ketentuan hukum acara tersebut.

Disisi lain ada pihak yang belum bisa menggunakan teknologi informasi dan ketersediaan jaringan internet di daerah tertentu. Meski sudah ada nota kesepahaman terkait penggunaan video conference perkara pidana, terutama untuk pemeriksaaan saksi, namun ketersediaan perangkat elektronik di masing-masing instansi, posisi terdakwa, dan keberadaan pihak terkait (saksi) belum merata dan memadai. ${ }^{4}$

Pelaksanaan persidangan online ini berpotensi dapat mengganggu prinsip fair trial (peradilan jujur dan adil), jika infrastruktur untuk mendukung peradilan online yang kurang memadai dan juga potensial mengurangi keabsahan dalam proses pembuktian. Selain itu antara hakim, jaksa, terdakwa, penasihat hukum dan saksi tidak dalam satu ruangan yang sama. Potensi untuk terjadinya tekanan yang dilakukan dari berbagai pihak dari proses persidangan ataupun pembuktian akan memungkinkan terjadi.

Pada pasal 154 KUHAP meskipun tidak secara eksplisit disebutkan bahwa Terdakwa wajib hadir dalam persidangan. Namun dari ketujuh ayat pada Pasal 154 KUHAP menegaskan bahwa Terdakwa sepatutnya hadir dan tidak diperbolehkan untuk diwakili dalam

${ }^{3}$ RR. Dewi Anggraeni, Wabah Pandemi Covid-19, Urgensi Pelaksanaan Sidang Secara Elektronik, ADALAH: Buletin Hukum dan Keadilan, Volome 4, Nomor 1, 2020, hlm. 7.

${ }^{4}$ Hamidah Abdurrachman, Legalitas Persidangan Online Dalam Sistem Peradilan Pidana Indonesia, Univeritas Bung Hatta, https://hukum.bunghatta.ac.id, diakses tanggal 15 Juli 2020. 
persidangan berdasarkan surat panggilan oleh Jaksa Penuntut Umum. ${ }^{5}$ KUHAP tidak memperbolehkan proses peradilan in absentia dalam acara pemeriksaan biasa dan pemeriksaan singkat hal ini dapat di lihat pada Pasal 154 ayat (4) KUHAP. ${ }^{6}$ Asas kehadiran terdakwa ini biasa dikenal dalam tindak pidana khusus seperti pada tindak pidana korupsi dan tindak pidana ekonomi. Asas kehadiran terdakwa ini memiliki sebutan lain yakni ius singular, ius speciale, atau bizonder strafrecht. ${ }^{7}$ Selain itu Asas Kehadiran terdakwa ini berhubungan dengan Asas Pemeriksaan Hakim yang Langsung dan Lisan. ${ }^{8}$

Menjadi sangat rawan ketidakadilan apabila dihubungkan dengan ketentuan bahwa hakim tidak boleh menjatuhkan pidana kepada seseorang kecuali apabila dengan sekurangkurangnya dua alat bukti yang sah ia memperoleh keyakinan bahwa suatu tindak pidana benar-benar terjadi dan bahwa terdakwalah yang bersalah melakukannya. ${ }^{9}$ Jika dalam pelaksaan persidangan online ini mengalami kendala teknis maka dalam hal agenda pembuktian pemeriksaan saksi dan/ atau ahli maupun keterangan terdakwa dan alat bukti lainnya tidak dapat dilakukan secara maksimal. Belum lagi penasihat hukum tidak berada berdampingan dengan terdakwa, dan tidak dapat memastikan saksi dan terdakwa dalam tekanan/dusta sehingga mempengaruhi prinsip pengungkapan kebenaran materiil dalam hukum pidana.

Sehingga atas dasar pandangan tersebut maka peneliti tertarik untuk melakukan kajian ini lebih lanjut tentang eksistensi persidangan online dalam perkara pidana ditengah pandemi Covid-19 ini terutama menganalisis pada mekanisme penerapan hukum acara dan proses pembuktian.

\section{RUMUSAN MASALAH}

Berdasarkan latar belakang masalah diatas, maka dapat dirumuskan suatu rumusan masalah yang akan diteliti sebagai berikut:

1. Bagaimana mekanisme penerapan hukum acara pada persidangan online dalam perkara pidana di Indonesia?

\footnotetext{
${ }^{5}$ Pasal 152 Ayat (2) Undang-Undang Nomor 8 Tahun 1981 Tentang Hukum Acara Pidana (KUHAP).

${ }^{6}$ Aristo M.A. Pangaribuan, Arsa Mufti, dan Ichsan Zikry, 2017, Pengantar Hukum Acara Pidana di Indonesia, Jakarta: Raja Grafindo, hlm. 245.

${ }^{7}$ Lilik Mulyadi, 2012, Hukum Acara Pidana Indonesia: Suatu Tinjauan Khusus Terhadap Surat Dakwaan, Eksepsi,dan Putusan Pengadilan, Bandung: PT. Citra. Aditya Bakti, hlm. 16.

${ }^{8}$ Andi Hamzah, 2009, Hukum Acara Pidana, Jakarta: Sinar Grafika, hlm 25.

${ }^{9}$ Pasal 183 Undang-Undang Nomor 8 Tahun 1981 Tentang Hukum Acara Pidana (KUHAP).
} 
2. Bagaimana persidangan online mengakomodir proses pembuktian dalam perkara pidana di Indonesia?

\section{METODE PENELITIAN}

Penelitian ini dilakukan dengan menggunakan jenis penelitian hukum normatif, yaitu penelitian kepustakaan yang menggunakan 3 (tiga) bahan hukum yaitu bahan hukum primer, bahan hukum sekunder dan bahan hukum tersier. Penelitian ini menitikberatkan pada studi kepustakaan yang dalam pengkajiannya mengacu dan mendasarkan pada norma-norma, kaidah-kaidah hukum, peraturan perundang- undangan yang berlaku, teori-teori atau doktrin hukum, yurisprudensi, dan bahan- bahan kepustakaan lainnya yang relevan dengan topik penelitian.

Pengumpulan bahan hukum dilakukan dengan studi pustaka yakni melalui pengakajian terhadap Undang-Undang Nomor 8 Tahun 1981 tentang Hukum Acara Pidana atau Kitab Undang-Undang Hukum Acara Pidana (KUHAP) dan Peraturan Mahkamah Agung Nomor 1 tahun 2019 tentang Tata Cara Persidangan Secara Elektronik, Surat Edaran Mahkamah Agung (SEMA) Nomor 3 Tahun 2020 tertanggal 20 April 2020 tentang perubahan kedua atas Surat Edaran Mahkamah Agung Nomor 1 Tahun 2020 tentang Pedoman Pelaksanaan Tugas Selama Masa Pencegahan Penyebaran Covid-19 di Lingkungan Mahkamah Agung dan Badan Peradilan yang berada di Bawahnya, Perjanjian Kerjasama/ MoU antara Mahkamah Agung, Kejaksaan Agung, dan Kementerian Hukum dan HAM tanggal 13 April 2020 No. 402/DJU/KM.01.1/4/2020; KEP-17/E/Ejp/04/2020; PAS-08.HH.05.05.Tahun 2020 tentang Pelaksanaan Persidangan Melalui Teleconference, Peraturan Mahkamah Agung Nomor 4 Tahun 2020 tentang Administrasi dan Persidangan Perkara Pidana di Pengadilan Secara Elektronik serta berbagai pustaka yang relevan dengan objek penelitian.

Pendekatan penelitian yang peneliti pergunakan dalam penelitian ini adalah pendekatan statute approach yaitu pendekatan peraturan perundang- undangan yang menitikberatkan pada bahan hukum primer yang mengatur tentang alat bukti elektronik dalam sistem pembuktian perkara pidana di Indonesia .

Analisis bahan hukum yang digunakan dalam penelitian ini adalah dengan metode kualitatif, yaitu bahan hukum yang telah terkumpul dari studi dokumen dikelompokkan sesuai dengan permasalahan yang akan dibahas. Bahan hukum tersebut kemudian ditafsirkan dan dianalisis guna mendapatkan kejelasan (pemecahan dari masalah yang akan dibahas). Dengan 
kata lain analisis bahan hukum dengan metode ini akan menemukan suatu kesimpulan yang dituangkan dalam bentuk pernyataan atau tulisan.

\section{PEMBAHASAN}

\section{Mekanisme Penerapan Hukum Acara Pada Persidangan Online Dalam Perkara Pidana di Indonesia}

Saat pandemi Covid-19 ini dimana sesuai dengan protokol kesehatan yang ditetapkan oleh pemerintah agenda persidangan harus dilakukan secara online dengan perangkat atau sistem informasi elektronik dimana para pihak berada pada tempatnya masing-masing dengan dasar hukum Peraturan Mahkamah Agung Nomor 1 tahun 2019 tentang Tata Cara Persidangan Secara Elektronik, kemudian Mahkamah Agung (MA) telah mengeluarkan Surat Edaran Nomor 1 Tahun 2020 tentang Pedoman Pelaksanaan Tugas Selama Masa Pencegahan Penyebaran Corona Virus Disease (Covid-19) di Lingkungan Mahkamah Agung dan Badan Peradilan yang Berada di Bawahnya (SEMA Nomor 1 Tahun 2020). SEMA Nomor 1 Tahun 2020 kemudian diubah dengan SEMA Nomor 2 Tahun 2020 dan diubah lagi dengan SEMA Nomor 3 Tahun 2020. Peraturan tersebut mengatur hakim dan aparatur peradilan dapat menjalankan tugas kedinasan dengan bekerja di rumah atau tempat tinggalnya (work from home/WFH). WFH tersebut termasuk pelaksanaan agenda persidangan pemeriksaan perkara yang dilakukan secara elektronik melalui teleconference.

Kebijakan untuk melakukan persidangan secara elektronik diperkuat dengan adanya sebuah MoU (Memorandum of Understanding) kesepakatan antara pihak Mahkamah Agung, Kejaksaan Republik Indonesia dan Kementerian Hukum dan HAM dalam hal ini Direktorat Jenderal Pemasyarakatan disahkan tanggal 13 April 2020 No. 402/DJU/KM.01.1/4/2020; KEP-17/E/Ejp/04/2020; PAS-08.HH.05.05.Tahun 2020 tentang Pelaksanaan Persidangan Melalui teleconference $\mathrm{MoU}$ tersebut terkait kesepakatan pelaksanaan persidangan selama masa pandemi Covid-19 yang akan dilaksanakan sampai dengan berakhirnya wabah Covid-19 di Indonesia.

Sebagai tindak lanjut dari MoU tersebut Mahkamah Agung (MA) telah menerbitkan Peraturan Mahkamah Agung Nomor 4 Tahun 2020 tentang Administrasi dan Persidangan Perkara Pidana di Pengadilan Secara Elektronik (Perma Sidang Pidana Online). Perma ini mengatur tata cara pelaksanaan persidangan perkara pidana baik perkara pidana dalam lingkup peradilan umum, militer, maupun jinayat secara daring (online). Perma yang diteken 
Ketua MA M. Syarifuddin pada 25 September 2020 ini disusun oleh Pokja berdasarkan SK KMA No. 108/KMA/IV/2020 tentang Kelompok Kerja Administrasi dan Persidangan Perkara Pidana di Pengadilan Secara Elektronik.

Berikut adalah mekanisme atau administrasi persidangan perkara pidana yang dilakukan secara online yang dapat dirangkumkan sebagaimana diatur dalam Peraturan Mahkamah Agung Nomor 4 Tahun 2020 tentang Administrasi dan Persidangan Perkara Pidana di Pengadilan Secara Elektronik:

1. Persiapan Persidangan

a. Sebelum acara persidangan dimulai, panitera/ panitera pengganti mengecek seluruh kesiapan peserta sidang dan melaporkan kepada Hakim/Majelis Hakim. ${ }^{10}$

b. Dalam sidang yang dilakukan secara elektronik, terdakwa yang didampingi oleh penasihat hukum harus secara fisik berada di ruangan yang sama dengan penasihat hukumnya. $^{11}$

c. Diruangan tempat dimana terdakwa mengikuti persidangan secara elektronik tidak diperkenankan terdapat orang lain selain terdakwa dan penasihat hukumnya, kecuali untuk petugas Rutan/Lapas, tenaga IT, dan petugas/pihak lain yang wajib mendampingi terdakwa sesuai ketentuan peraturan perundang-undangan. ${ }^{12}$

d. Ruangan tempat terdakwa disidangkan wajib dilengkapi dengan alat perekam/kamera/CCTV yang dapat memperlihatkan kondisi ruangan secara keseluruhan. $^{13}$

e. Dalam persidangan, panitera pengganti mencatat suasana ruangan tempat penuntut umum dan Terdakwa/Penasihat Hukum dalam berita acara sidang. ${ }^{14}$

2. Dakwaan dan Keberatan

a. Dokumen keberatan/eksepsi dikirim kepada Hakim/Majelis Hakim dan filenya diteruskan kepada penuntut dalam bentuk Portable Document Format (PDF) yang

${ }^{10}$ Pasal 7 Ayat (1) Peraturan Mahkamah Agung Nomor 4 Tahun 2020 Tentang Adminstrasi dan Persidangan Perkara Pidana di Pengadilan Secara Elektronik.

${ }_{11}$ Pasal 7 Ayat (2) Peraturan Mahkamah Agung Nomor 4 Tahun 2020 Tentang Adminstrasi dan Persidangan Perkara Pidana di Pengadilan Secara Elektronik.

${ }_{12}$ Pasal 7 Ayat (4) Peraturan Mahkamah Agung Nomor 4 Tahun 2020 Tentang Adminstrasi dan Persidangan Perkara Pidana di Pengadilan Secara Elektronik.

${ }^{13}$ Pasal 7 Ayat (5) Peraturan Mahkamah Agung Nomor 4 Tahun 2020 Tentang Adminstrasi dan Persidangan Perkara Pidana di Pengadilan Secara Elektronik.

${ }^{14}$ Pasal 7 Ayat (6) Peraturan Mahkamah Agung Nomor 4 Tahun 2020 Tentang Adminstrasi dan Persidangan Perkara Pidana di Pengadilan Secara Elektronik. 
dikirim ke alamat pos elektronik pengadilan yang menyidangkan perkara sebelum dibacakan dan diverifikasi anatara yang dibacakan dengan yang diunduh. ${ }^{15}$

b. Pendapat penuntut terhadap keberatan terdakwa/eksepsi dikirim kepada Hakim/Majelis Hakim diatur sebagimana dengan cara seperti diatas tersebut. ${ }^{16}$

c. Dalam keadaan tertentu, sidang pengucapan putusan/ putusan sela dapat dilangsungkan secara elektronik. ${ }^{17}$

3. Pemeriksaan Saksi dan Ahli

a. Pemeriksaan Saksi dan/atau Ahli dilakukan dalam ruang sidang Pengadilan meskipun persidangan dilakukan secara elektronik. ${ }^{18}$

b. Namun dalam keadaan tertentu, Hakim/Majelis Hakim dapat menetapkan pemeriksaan Saksi dan/atau Ahli sebagai berikut yang berada di: ${ }^{19}$

1) Kantor penuntut dalam daerah hukumnya;

2) Pengadilan tempat Saksi dan /atau Ahli berada apabila yang bersangkutan berada di dalam dan di luar daerah hukum pengadilan yang menyidangkan perkara;

3) Kedutaan/konsulat jenderal Republik Indonesia atas persetujuan/rekomendasi Menteri Luar Negeri, dalam hal saksi/ahli berada di luar negeri; atau

4) Tempat lain yang ditentukan oleh Hakim/Majelis Hakim.

\section{Pemeriksaan Terdakwa}

a. Dalam pemeriksaan terdakwa pada sidang yang dilakukan secara elektronik, maka dilakukan hal berikut: ${ }^{20}$

1) Terdakwa yang berada dalam tahanan didengar keterangannya dari tempat ia ditahan dengan didampingi/tidak didampingi oleh penasihat hukum;

15 Pasal 8 Ayat (2) Peraturan Mahkamah Agung Nomor 4 Tahun 2020 Tentang Adminstrasi dan Persidangan Perkara Pidana di Pengadilan Secara Elektronik Juncto Pasal 3 ayat (1), (2), dan (3) Peraturan Mahkamah Agung Nomor 4 Tahun 2020 Tentang Adminstrasi dan Persidangan Perkara Pidana di Pengadilan Secara Elektronik.

${ }^{16}$ Pasal 8 Ayat (3) Peraturan Mahkamah Agung Nomor 4 Tahun 2020 Tentang Adminstrasi dan Persidangan Perkara Pidana di Pengadilan Secara Elektronik.

${ }_{17}$ Pasal 9 Ayat (2) Peraturan Mahkamah Agung Nomor 4 Tahun 2020 Tentang Adminstrasi dan Persidangan Perkara Pidana di Pengadilan Secara Elektronik.

${ }_{18}$ Pasal 11 Ayat (2) Peraturan Mahkamah Agung Nomor 4 Tahun 2020 Tentang Adminstrasi dan Persidangan Perkara Pidana di Pengadilan Secara Elektronik.

${ }_{19}$ Pasal 11 Ayat (3) Peraturan Mahkamah Agung Nomor 4 Tahun 2020 Tentang Adminstrasi dan Persidangan Perkara Pidana di Pengadilan Secara Elektronik.

${ }^{20}$ Pasal 13 Ayat (2) Peraturan Mahkamah Agung Nomor 4 Tahun 2020 Tentang Adminstrasi dan Persidangan Perkara Pidana di Pengadilan Secara Elektronik. 
2) Terdakwa yang berada dalam tahanan, tetapi tempat terdakwa ditahan tidak memiliki fasilitas untuk sidang elektronik, didengar keterangannya dari kantor penuntut; atau

3) Apabila terdakwa tidak ditahan, didengar keterangannya di pengadilan, kantor penuntut, atau tempat lain yang ditentukan oleh Hakim/Majelis Hakim melalui penetapan.

b. Apabila terdakwa tidak ditahan, ketua/kepala pengadilan tempat terdakwa didengar keterangannya menyediakan fasilitas persidangan secara elektronik serta menunjuk 1 orang Hakim dan 1 orang Panitera/Panitera Pengganti tanpa menggunakan atribut persidangan untuk mengawasi jalannya pemeriksaan Terdakwa. ${ }^{21}$

5. Pemeriksaan Barang Bukti

a. Pada sidang yang dilakukan secara elektronik, barang bukti yang akan diperiksa tetap berada di kantor penuntut. Kemudian penuntut memperlihatkan barang bukti ke Hakim/Majelis Hakim secara elektronik. ${ }^{22}$

b. Apabila barang bukti tersebut berupa dokumen cetak, maka Hakim/Majelis Hakim akan mencocokkan dokumen hasil pindai yang ada dalam berkas perkara dengan dokumen asli yang diperlihatkan penuntut secara elektronik. ${ }^{23}$

c. Apabila barang bukti tersebut bukan dokumen cetak, maka barang bukti bisa difoto/divideokan kemudian dikirim ke alamat pos-elektronik Pengadilan sebelum diajukan sebagai barang bukti. ${ }^{24}$

d. Apabila Terdakwa mengajukan barang bukti yang meringankan, baik berupa dokumen cetak maupun bukan dokumen cetak, maka barang bukti tersebut diperlakukan sama dengan hal di atas. ${ }^{25}$

e. Hakim/Majelis Hakim mencocokkan barang bukti yang dikirim dengan aslinya secara elektronik. ${ }^{26}$

${ }^{21}$ Pasal 13 Ayat (3) Peraturan Mahkamah Agung Nomor 4 Tahun 2020 Tentang Adminstrasi dan Persidangan Perkara Pidana di Pengadilan Secara Elektronik.

${ }_{22}$ Pasal 14 Ayat (1) dan Ayat (2) Peraturan Mahkamah Agung Nomor 4 Tahun 2020 Tentang Adminstrasi dan Persidangan Perkara Pidana di Pengadilan Secara Elektronik.

${ }^{23}$ Pasal 14 Ayat (3) Peraturan Mahkamah Agung Nomor 4 Tahun 2020 Tentang Adminstrasi dan Persidangan Perkara Pidana di Pengadilan Secara Elektronik.

${ }^{24}$ Pasal 14 Ayat (4) Peraturan Mahkamah Agung Nomor 4 Tahun 2020 Tentang Adminstrasi dan Persidangan Perkara Pidana di Pengadilan Secara Elektronik.

${ }^{25}$ Pasal 14 Ayat (5) Peraturan Mahkamah Agung Nomor 4 Tahun 2020 Tentang Adminstrasi dan Persidangan Perkara Pidana di Pengadilan Secara Elektronik.

${ }^{26}$ Pasal 14 Ayat (6) Peraturan Mahkamah Agung Nomor 4 Tahun 2020 Tentang Adminstrasi dan Persidangan Perkara Pidana di Pengadilan Secara Elektronik. 
6. Tuntutan, Pembelaan, Replik dan Duplik

a. Tuntutan pidana, pembelaan, replik dan duplik dibacakan dimuka sidang sesuai dengan ketentuan Hukum Acara. ${ }^{27}$

b. Apabila sidang dilaksanakan secara elektronik, maka dokumen tuntutan pidana, pembelaan, replik dan duplik dikirim ke alamat pos-elektronik pengadilan sebelum dibacakan, serta setelah dibacakan, dokumen itu dikirim ke alamat pos-elektronik penuntut/terdakwa dan/atau penasihat hukum. ${ }^{28}$

7. Putusan dan Pemberitahuan Putusan

a. Putusan diucapkan oleh Hakim/Majelis Hakim di sidang yang terbuka untuk umum dengan dihadiri penuntut dan terdakwa/penasihat hukum, terkecuali ditentukan lain oleh undang-undang. ${ }^{29}$

b. Tetapi dalam keadaan tertentu, berdasarkan penetapan Hakim/Majelis Hakim, sidang pengucapan putusan dapat dilangsungkan secara elektronik. ${ }^{30}$

c. Apabila terdakwa tidak hadir dalam pembacaan putusan, pemberitahuan putusan disampaikan oleh Pengadilan kepada terdakwa melalui domisili elektronik berupa pos-elektronik, alamat Whatsapp, atau SMS. ${ }^{31}$

d. Apabila terdakwa tidak memiliki domisili elektronik, maka putusan akan disampaikan melalui surat tercatat ke alamat tempat tinggal terdakwa dengan tembusan kepada kepala desa atau lurah. Apabila terdakwa tidak diketahui tempat tinggal dan tempat kediamannya, maka pemberitahuan putusan dilakukan melalui media massa, papan pengumuman dan website pengadilan. ${ }^{32}$

Kemudian sebelum acara persidangan secara online dilaksanakan, maka harus memperhatikan atau mempersiapkan seperti hal-hal berikut, yaitu:

${ }^{27}$ Pasal 15 Ayat (1) Peraturan Mahkamah Agung Nomor 4 Tahun 2020 Tentang Adminstrasi dan Persidangan Perkara Pidana di Pengadilan Secara Elektronik.

${ }_{28}$ Pasal 15 Ayat (2) Peraturan Mahkamah Agung Nomor 4 Tahun 2020 Tentang Adminstrasi dan Persidangan Perkara Pidana di Pengadilan Secara Elektronik Juncto Pasal 3 Ayat (2) dan Ayat (4) Peraturan Mahkamah Agung Nomor 4 Tahun 2020 Tentang Adminstrasi dan Persidangan Perkara Pidana di Pengadilan Secara Elektronik.

${ }^{29}$ Pasal 16 Ayat (1) Peraturan Mahkamah Agung Nomor 4 Tahun 2020 Tentang Adminstrasi dan Persidangan Perkara Pidana di Pengadilan Secara Elektronik.

${ }^{30}$ Pasal 16 Ayat (2) Peraturan Mahkamah Agung Nomor 4 Tahun 2020 Tentang Adminstrasi dan Persidangan Perkara Pidana di Pengadilan Secara Elektronik.

${ }^{31}$ Pasal 16 Ayat (3) Peraturan Mahkamah Agung Nomor 4 Tahun 2020 Tentang Adminstrasi dan Persidangan Perkara Pidana di Pengadilan Secara Elektronik.

32 Pasal 16 Ayat (4) dan Ayat (5) Peraturan Mahkamah Agung Nomor 4 Tahun 2020 Tentang Adminstrasi dan Persidangan Perkara Pidana di Pengadilan Secara Elektronik. 
1. Semua peserta sidang wajib terlihat di layar dengan terang dan jelas dan dengan suara yang jernih. ${ }^{33}$

2. Panitera/Panitera pengganti mempersiapkan sarana persidangan termasuk kesiapan peserta sidang dan melaporkan kepada majelis hakim. ${ }^{34}$

3. Dalam persidangan hakim, panitera pengganti, penuntut dan penasihat hukum menggunakan atribut sidang masing-masing sesuai dengan ketentuan hukum acara yang berlaku. $^{35}$

4. Setiap dokumen yang disampaikan oleh penuntut, penasihat hukum, dan terdakwa harus berbentuk dokumen elektronik dengan format Portable Document Format (PDF). ${ }^{36}$

5. Setiap dokumen elektronik yang dikirim, harus diunduh dan diverifikasi antara yang dibacakan dengan yang diunduh. ${ }^{37}$

Mekanisme sebagaimana diatur pada hal diatas dalam persidangan online memang tidak diatur dalam KUHAP, tetapi dapat dipahami bahwa Perma tersebut memberikan 2 (dua) alternatif untuk melakukan persidangan dalam perkara pidana, yaitu secara offline dan secara online. Dilakukan secara offline maksudnya bahwa persidangan dilakukan seperti pada umumnya, yakni semua peserta sidang dan prosesnya berada didalam satu ruangan sidang di pengadilan secara langsung tanpa melalui media elektronik. Akan tetapi jika hal tersebut memungkinkan untuk dilakukan sebagaimana diatur dalam Pasal 2 Ayat (1) Perma tersebut yang berbunyi: "Persidangan dilaksanakan di ruangan sidang Pengadilan dengan dihadiri Penuntut dan Terdakwa dengan didampingi/tidak didampingi oleh Penasihat Hukum, kecuali ditentukan lain berdasarkan ketentuan peraturan perundang-undangan". 38

Jika tidak dimungkinkannya dilaksanakan sidang secara offline dan dalam keadaan tertentu seperti saat ini masih dalam situasi pandemi Covid-19, maka persidangan dapat dilakukan secara online baik sejak awal persidangan perkara maupun pada saat persidangan perkara sedang berlangsung. Berkaitan dengan akses publik pada persidangan online maka

${ }^{33}$ Pasal 2 Ayat (3) Peraturan Mahkamah Agung Nomor 4 Tahun 2020 Tentang Adminstrasi dan Persidangan Perkara Pidana di Pengadilan Secara Elektronik.

${ }^{34}$ Pasal 2 Ayat (4) Peraturan Mahkamah Agung Nomor 4 Tahun 2020 Tentang Adminstrasi dan Persidangan Perkara Pidana di Pengadilan Secara Elektronik.

${ }_{35}$ Pasal 2 Ayat (5) Peraturan Mahkamah Agung Nomor 4 Tahun 2020 Tentang Adminstrasi dan Persidangan Perkara Pidana di Pengadilan Secara Elektronik.

${ }^{36}$ Pasal 3 Ayat (1) Peraturan Mahkamah Agung Nomor 4 Tahun 2020 Tentang Adminstrasi dan Persidangan Perkara Pidana di Pengadilan Secara Elektronik.

37 Pasal 3 Ayat (3) Peraturan Mahkamah Agung Nomor 4 Tahun 2020 Tentang Adminstrasi dan Persidangan Perkara Pidana di Pengadilan Secara Elektronik.

${ }^{38}$ Pasal 2 Ayat (1) Peraturan Mahkamah Agung Nomor 4 Tahun 2020 Tentang Adminstrasi dan Persidangan Perkara Pidana di Pengadilan Secara Elektronik. 
dalam Pasal 18 Perma tersebut dinyatakan bahwa akses publik terhadap administrasi dan persidangan dilakukan sesuai dengan ketentuan peraturan perundang-undangan yang berlaku.

Persidangan secara online ini memang merupakan bagian dari reformasi sistem peradilan di Indonesia yang lebih modern dan pembaharuan hukum di Indonesia terlebih pada saat pandemi Covid-19 ini. Dimana diperlukan kebijakan yang progresif dalam rangka memecahkan permasalahan stagnasi perkara akibat penyebaran Covid-19 jika persidangan hanya dilakukan secara offline. Selain itu agar pemenuhan terhadap hak-hak hukum bagi terdakwa tetap terpenuhi secara maksimal. Misalnya asas peradilan yang cepat (tidak berteletele), sederhana (karena dilakukan melalui media elektronik atau teleconference), dan biaya ringan benar-benar bisa dirasakan bagi pencari keadilan.

Persidangan online ini bentuk dari progresifitas hukum yang mengedepankan pada prinsip-prinsip dasar hukum yaitu kebutuhan masyarakat akan hukum itu sendiri, kepastian hukum, kemanfaatan, dan keadilan. Sehingga pada dasarnya tidak bertentangan dengan Hukum Acara sekalipun tidak diatur dalam peraturan perundang-undangan. Persidangan online ini bersifat sebagai quasi court dan darurat abnormal sehingga harus dimaknai tidak terikat secara ketat pada aturan formal dan materil. ${ }^{39}$

Penyelenggaraan sidang perkara pidana secara online jarak jauh atau teleconference ditengah pandemi global Covid-19 seperti sekarang ini merupakan bentuk terobosan yang paling tepat dan harus terus disempurnakan oleh Mahkamah Agung, sebab lambatnya pembaruan hukum di Indonesia (Expired Law) akan melanggar pemenuhan jaminan hak hukum setiap individu yang sedang berhadapan dengan hukum. ${ }^{40}$ Dan yang telah dilakukan oleh MA tersebut adalah bentuk pertanggungjawaban publik untuk memberikan pelayanan yang cepat, sederhana, dan akurat tanpa menunda atau menghambat masyarakat memperoleh akses keadilan. Karena bagi MA, Justice Delayed, Justice Denied, yang artinya "Keadilan yang Tertunda, Sama Seperti Tidak Ada Keadilan". 41

Namun dalam penerapan persidangan online pada perkara pidana ini sebagai bagian dari pembaharuan hukum harus tetap dilakukan secara cermat dan teliti terutama menyangkut pada asas-asas sistem peradilan pidana yang lain, misalnya terdakwa, saksi dan/ atau ahli diperlakukan secara adil dimuka hukum (tidak diskriminatif dan tidak dalam tekanan) hal ini

39 Indriyanto Seno Adji, Persidangan Online Adalah Quasi Court, BeritaHukum.com, http://m.beritahukum.com/detail_berita.php, diakses pada tanggal 29 Maret 2020.

${ }^{40}$ Wahyu Iswantoro, Persidangan Pidana Secara Online, Respon Cepat MA Hadapi Pandemi Covid19, Selisik, Volume 6 Nomor 1, Juni 2020, hlm. 60.

${ }^{41}$ Ibid, hlm. 63. 
mengingat persidangan dilakukan diruangan yang berbeda. Kemudian asas terbuka untuk umum (akses publik) harus menjadi perhatian mengingat pada persidangan online akses publik sangat terbatas.

\section{Proses Pembuktian pada Perkara Pidana dalam Persidangan Online di Indonesia}

Dalam konteks hukum acara pidana, pembuktian merupakan inti persidangan perkara pidana karena yang dicari dalam hukum acara pidana adalah kebenaran materiil, yang menjadi tujuan pembuktian adalah benar bahwa suatu tindak pidana telah terjadi dan terdakwalah yang bersalah melakukannya. Untuk membuktikan kesalahan terdakwa, pengadilan terikat oleh cara-cara/ ketentuan-ketentuan pembuktian sebagaimana diatur dalam undang-undang. Pembukian yang sah harus dilakukan di dalam sidang pengadilan sesuai dengan prosedur/cara-cara yang berlaku dalam hukum pembuktian. ${ }^{42}$

Dalam perkara pidana terdapat 5 (lima) alat bukti yang sah berdasarkan Pasal 184 Kitab Undang-Undang Hukum Acara Pidana, yaitu keterangan saksi, keterangan ahli, surat, keterangan terdakwa dan petunjuk. Kemudian ada tambahan alat bukti baru yang diakui berdasarkan Undang-Undang No. 11 Tahun 2008 tentang Informasi dan Transaksi Elektronik yaitu alat bukti elektronik (electronic evidence).

Terkait dengan pemeriksaan saksi / dan atau ahli dalam proses pembuktian perkara pidana dipersidangan online maka diatur sebagaimana hal berikut: ${ }^{43}$

1. Jika dalam keadaan tertentu, maka Hakim/ Majelis Hakim dapat penetapkan pemeriksaan saksi dan/ atau ahli yang berada di:

a. Kantor penuntut dalam daerah hukumnya;

b. Pengadilan tempat Saksi dan /atau Ahli berada apabila yang bersangkutan berada di dalam dan di luar daerah hukum pengadilan yang menyidangkan perkara;

c. Kedutaan/konsulat jenderal Republik Indonesia atas persetujuan/rekomendasi Menteri Luar Negeri, dalam hal saksi/ahli berada di luar negeri; atau

d. Tempat lain yang ditentukan oleh Hakim/Majelis Hakim.

2. Pemeriksaan saksi yang identitasnya menurut hakim/ majelis hakim wajib dirahasiakan, maka fitur video dalam tampilan aplikasi pelaksanaan sidang tersebut harus

\footnotetext{
${ }^{42}$ Hanafi dan Reza Aditya Pamuji, Urgensi Keterangan Ahli Sebagai Alat Bukti Berdasarkan Sistem Peradilan Pidana di Indonesia, Jurnal Al'Adl, Volume 10 Nomor 1, Januari 2019. hlm. 84.

${ }^{43}$ Pasal 11 Ayat (1), Ayat (2), dan Ayat (3) Peraturan Mahkamah Agung Nomor 4 Tahun 2020 Tentang Adminstrasi dan Persidangan Perkara Pidana di Pengadilan Secara Elektronik.
} 
dinonaktifkan dan suaranya harus disamarkan. Atau mendengarkan keterangan saksi tersebut tanpa dihadiri oleh terdakwa. ${ }^{44}$

Terkait dengan pemeriksaan terdakwa sebagaimana diatur dalam Perma tersebut diatur mengenai hal-hal berikut, yaitu:

1. Pemeriksaan terdakwa dilakukan diruang sidang sesuai dengan ketentuan Hukum Acara. $^{45}$

2. Dalam pemeriksaan terdakwa pada sidang yang dilakukan secara elektronik, maka dilakukan hal berikut: ${ }^{46}$

a. Terdakwa yang berada dalam tahanan didengar keterangannya dari tempat ia ditahan dengan didampingi/tidak didampingi oleh penasihat hukum;

b. Terdakwa yang berada dalam tahanan, tetapi tempat terdakwa ditahan tidak memiliki fasilitas untuk sidang elektronik, didengar keterangannya dari kantor penuntut; atau

c. Apabila terdakwa tidak ditahan, didengar keterangannya di pengadilan, kantor penuntut, atau tempat lain yang ditentukan oleh Hakim/Majelis Hakim melalui penetapan.

3. Apabila terdakwa tidak ditahan, ketua/kepala pengadilan tempat terdakwa didengar keterangannya menyediakan fasilitas persidangan secara elektronik serta menunjuk 1 orang Hakim dan 1 orang Panitera/Panitera Pengganti tanpa menggunakan atribut persidangan untuk mengawasi jalannya pemeriksaan Terdakwa. ${ }^{47}$

Berdasarkan ketentuan dalam Perma tersebut diatas, maka berkaitan dengan keterangan saksi, keterangan ahli, dan keterangan terdakwa pada sidang yang dilakukan secara online pada dasarnya tetap mengikuti ketentuan dalam hukum acara pidana dan memiliki nilai atau kekuatan pembuktian yang sama dengan sidang yang dilakukan secara offline walaupun tidak diatur secara khusus oleh KUHAP.

Apabila mengacu pada cara berfikir formal-legalistik, maka teleconference memang tampak tidak sesuai dengan ketentuan Pasal 160 ayat (1) huruf a dan Pasal 167 KUHAP yang menghendaki kehadiran saksi secara fisik di ruang sidang. Namun, Majelis Hakim pada saat

\footnotetext{
${ }^{44}$ Pasal 12 Peraturan Mahkamah Agung Nomor 4 Tahun 2020 Tentang Adminstrasi dan Persidangan Perkara Pidana di Pengadilan Secara Elektronik.

${ }^{45}$ Pasal 13 Ayat (1) Peraturan Mahkamah Agung Nomor 4 Tahun 2020 Tentang Adminstrasi dan Persidangan Perkara Pidana di Pengadilan Secara Elektronik.

${ }^{46}$ Pasal 13 Ayat (2) Peraturan Mahkamah Agung Nomor 4 Tahun 2020 Tentang Adminstrasi dan Persidangan Perkara Pidana di Pengadilan Secara Elektronik.

${ }_{47}$ Pasal 13 Ayat (3) Peraturan Mahkamah Agung Nomor 4 Tahun 2020 Tentang Adminstrasi dan Persidangan Perkara Pidana di Pengadilan Secara Elektronik.
} 
itu juga menimbang ketentuan Pasal 5 ayat (1) UU No. 48 Tahun 2009 tentang Kekuasaan Kehakiman yang mewajibkan Hakim sebagai penegak hukum dan keadilan untuk menggali, mengikuti, dan memahami dan mengejar kebenaran materiil dalam hukum pidana aspek formal hendaknya bisa ditinggalkan secara selektif. ${ }^{48}$

Dalam hal penggunaan video conference pada perkara pidana dalam agenda pemeriksaan saksi dan mendengar keterangannya sebelumnya sudah pernah digunakan di beberapa kasus. Namun penggunaanya terbatas hanya untuk mendengarkan keterangan dari saksi. Hal ini sebagaimana di atur di dalam Pasal 9 Ayat (3) Undang-Undang Nomor 31 Tahun 2014 tentang Perubahan Atas Undang-Undang Nomor 13 Tahun 2006 tentang Perlindungan Saksi dan Korban, di mana seorang saksi dapat didengar kesaksiannya secara langsung melalui sarana elektronik dengan didampingi oleh pejabat yang berwenang. Penggunaan video conference ini bertujuan untuk melindungi keamanan saksi dari berbagai ancaman atau demi mempermudah pemberian keterangan tanpa harus hadir di ruang sidang. Sementara itu pihak-pihak lain seperti Hakim, Penuntut Umum, Terdakwa dan pengacaranya tetap diwajibkan hadir di ruang sidang berdasarkan ketentuan peraturan perundangundangan. $^{49}$

Akan tetapi yang menjadi catatan dan perlu diperhatikan adalah sidang secara online ini sering menimbulkan kendala teknis, seperti sistem jaringan internet yang tidak stabil, suara dan/ atau gambar yang tidak jelas, dan sebagainya. Hal ini tentu membuat proses pembuktian menjadi tidak maksimal dan berpotensi mengganggu prinsip fair trial yaitu peradilan yang jujur dan adil. Dengan kata lain diperlukannya strategi-strategi dalam pembenahan persidangan online baik dengan melakukan kajian dari segi anggaran dalam rangka menunjang penguatan aset dan fasilitas terhadap penyelenggaraan Persidangan Pidana Daring dan juga melakukan evaluasi Sumber Daya Manusia (SDM) melalui pelaksanaan BIMTEK khusus di bidang IT; ${ }^{50}$ mendukung diterbitkannya aturan terbaru mengenai Standarisasi persidangan online agar proses persidangan online berjalan tanpa kendala berarti mulai dari tahap pembacaan dakwaan, pemeriksaan saksi-saksi, pemeriksaan terdakwa, pembacaan

\footnotetext{
${ }^{48}$ Dewi Rahmaningsih Nugroho dan S.Suteki, Membangun Budaya Hukum Persidangan Virtual (Studi Perkembangan Sidang Tindak Pidana via Telekonferensi), Jurnal Pembangunan Hukum Indonesia, Volume 2, Nomor 3, Juli 2020, hlm.296.

${ }^{49}$ Anggita Doramia Lumbanraja, Perkembangan Regulasi dan Pelaksanaan Persidangan Online di Indonesia dan Amerika Serikat Selama Pandemi Covid-19, Jurnal Crepido, Volume 02, Nomor 01, Juli 2020, hlm. 53.

${ }^{50}$ Anggi Astari Amelia Putri dan Dahlan Ali, Keabsahan Pembuktian Perkara Pidana Dalam Sidang yang Dilaksanakan Via Daring (Video Conference) Dalam Masa Pandemi Covid-19, Syiah Kuala Law Journal : Volume 4, Nomor 3, Desember 2020, hlm. 263.
} 
tuntutan, sampai pembacaan putusan. Sebab, Kitab Undang-Undang Hukum Acara Pidana (KUHAP) tidak mengakomodasi pemeriksaan persidangan melalui daring. ${ }^{51}$

Proses pembuktian perkara pidana pada sidang online ini memang akan menjadi tantangan tersendiri bagi hakim dalam mencari dan menggali kebenaran materiil terhadap suatu peristiwa pidana yang terjadi. Dalam Pasal 183 KUHAP bahwa hakim tidak boleh menjatuhkan pidana kepada seseorang kecuali apabila dengan sekurang-kurangnya dua alat bukti yang sah ia memperoleh keyakinan bahwa suatu tindak pidana benar-benar terjadi dan bahwa terdakwalah yang bersalah melakukannya.

Berkaitan dengan keyakinan hakim maka dalam teori sistem pembuktian keyakinan hakim tidak boleh berdiri sendiri melainkan harus bersumber pada alat-alat bukti atau minimal dua alat bukti yang sah menurut KUHAP, sekalipun hakim diberikan kewenangan subjektif untuk menilai apakah seseorang itu bersalah atau tidak. Apabila hakim mendasarkan putusannya hanya kepada keyakinannya semata, maka disitulah ketidakpastian hukum dan kesewenang-wenangan terjadi. ${ }^{52}$

Dalam teorinya hakim dapat memutuskan seseorang bersalah berdasarkan keyakinannya (Conviction In Time), namun keyakinan yang didasarkan kepada dasar-dasar pembuktian disertai dengan suatu kesimpulan (conclusive) yang berlandaskan kepada peraturan-peraturan pembuktian tertentu. Sehingga putusan hakim dijatukan dengan suatu motivasi. Teori pembuktian ini disebut juga pembuktian bebas karena hakim bebas untuk menyebutkan alasan-alasan keyakinannya berdasarkan pembuktian.

Sistem Conviction In Time ini menganut ajaran bahwa bersalah tidaknya terdakwa terhadap perbuatan yang didakwakan sepenuhnya tergantung pada penilaian keyakinan hakim semata-mata. Sehingga bersalah tidaknya terdakwa sepenuhnya tergantung pada keyakinan hakim. ${ }^{53}$ Dalam analisis hukum legalistik, yang cenderung bersifat kaku atau formal legalistik, persidangan online tidak dapat diterima sebagai media pemeriksaan perkara ${ }^{54}$ yang menghendaki kehadiran saksi di ruang persidangan. Namun, berbeda dengan ketentuan pada Pasal 5 ayat (1) Undang-Undang Nomor 48 Tahun 2009 tentang Kekuasaan Kehakiman

${ }^{51}$ Dian Cahyaningrum, Persidangan Secara Elektronik Pada Masa Pandemi Covid-19, Jurnal Hukum, Volume XII, No.14/II/Puslit, Juli 2020, hlm. 264.

${ }^{52}$ Subekti, 2015, Hukum Pembuktian, Jakarta: Pradnya Paramita, hlm. 2.

${ }^{53}$ Andi Hamzah, 2008, Hukum, Acara Pidana Indonesia, Jakarta: Sinar Grafika, hlm. 241.

${ }^{54}$ Pasal 160 Ayat (1) huruf a dan Pasal 167 Kitab Undang-Undang Hukum Acara Pidana. 
mewajibkan Hakim menggali kebenaran materiil, sehingga terbuka peluang bagi hakim untuk mengesampingkan aspek formal. ${ }^{55}$

Hal ini dapat dipahami bahwa keyakinan hakim tidak harus didasarkan pada alat bukti yang ada. Sekalipun alat bukti sudah cukup kalau hakim tidak yakin, hakim tidak boleh menjatuhkan pidana, sebaliknya meskipun alat bukti tidak ada tapi kalau hakim sudah yakin, maka terdakwa dapat dinyatakan bersalah. Akibatnya dalam memutuskan perkara hakim menjadi sangat subyektif dan berpotensi pada putusan yang diskriminatif.

Berdasarkan kemandirian dan prinsip kebebasan maka keyakinan hakim dalam memutus perkara harus dapat menegakkan kebenaran dan keadilan melalui berbagai cara seperti mampu menafsirkan undang-undang secara aktual, berani berperan menciptakan hukum baru atau sebagai pembentuk hukum, berani melakukan contra legem, mampu berperan mengadili secara kasuistik dan dapat memberikan akses menuju keadilan.

\section{PENUTUP}

Dari pembahasan di atas maka penelitian ini dapat disimpulkan menjadi 2 (dua) point penting, yaitu:

1. Mekanisme penerapan hukum acara pada persidangan online dalam perkara pidana sebagaimana diatur dalam PERMA No. 4 tahun 2020 tentang Adminstrasi dan Persidangan Perkara Pidana di Pengadilan Secara Elektronik memberikan 2 (dua) alternatif untuk melakukan persidangan dalam perkara pidana, yaitu secara offline dan secara online. Dilakukan secara offline maksudnya bahwa persidangan dilakukan seperti pada umumnya, yakni semua peserta sidang dan segala prosesnya berada didalam satu ruangan sidang di pengadilan secara langsung tanpa melalui media elektronik jika hal tersebut memungkinkan untuk dilakukan. Jika tidak dimungkinkannya dilaksanakan sidang secara offline dan dalam keadaan tertentu seperti saat ini masih dalam situasi pandemi Covid-19, maka persidangan dapat dilakukan secara online baik sejak awal persidangan perkara maupun pada saat persidangan perkara sedang berlangsung. Hal demikian memang tidak diatur sebelumnya di dalam Kitab Undang-Undang Hukum Acara Pidana (KUHAP) atau peraturan hukum lainnya. Persidangan secara online ini merupakan bagian dari reformasi sistem peradilan di Indonesia yang lebih modern dan

${ }^{55}$ Damayanti, Ruth Marina, (2014), Legalitas Keterangan Saksi Melalui Teleconference Sebagai Alat Bukti Dalam Perkara Pidana, Jurnal Program Pascasarjana Ilmu Hukum Universitas Muhammadiyah Surakarta, Vol. 5, No. 1, hlm. 6. 
pembaharuan hukum di Indonesia terlebih pada saat pandemi Covid-19 ini. Eksistensi persidangan online ini akan menjadi sebuah keniscayaan untuk beradaban dunia peradilan Indonesia dimasa yang akan datang dan tidak menutup kemungkinan akan tetap dilaksanakan walaupun pandemi Covid-19 ini sudah berakhir, sehingga agar tidak terjadi disharmonisasi hukum dan problematika hukum yang lebih serius maka perlu disempurnakan dengan adanya revisi terhadap Undang-Undang Nomor 8 Tahun 1981 tentang Hukum Acara Pidana (KUHAP).

2. Proses pembuktian dalam perkara pidana pada persidangan online pada dasarnya tetap mengikuti ketentuan dalam hukum acara pidana dan memiliki nilai atau kekuatan pembuktian yang sama dengan sidang yang dilakukan secara offline. Amanat Pasal 183 KUHAP bahwa hakim tidak boleh menjatuhkan pidana kepada seseorang kecuali apabila dengan sekurang-kurangnya dua alat bukti yang sah ia memperoleh keyakinan bahwa suatu tindak pidana benar-benar terjadi dan bahwa terdakwalah yang bersalah melakukannya. Berkaitan dengan keyakinan hakim maka dalam teori sistem pembuktian keyakinan hakim tidak boleh berdiri sendiri melainkan harus bersumber pada alat-alat bukti atau minimal dua alat bukti yang sah menurut KUHAP, sekalipun hakim diberikan kewenangan subjektif untuk menilai apakah seseorang itu bersalah atau tidak. Akan tetapi yang menjadi catatan dan perlu diperhatikan adalah sidang secara online ini sering menimbulkan kendala teknis seperti sistem jaringan internet yang tidak stabil, suara dan/ atau gambar yang tidak jelas, dan sebagainya. Hal ini tentu membuat proses pembuktian menjadi tidak maksimal dan berpotensi mengganggu prinsip fair trial yaitu peradilan yang jujur dan adil. Oleh karenanya harus ada standarisasi sarana dan prasarana persidangan online ini di pengadilan, memaksimalkan dan menambah tenaga IT disemua lembaga pengadilan, serta membentuk tim khusus yang independen untuk melakukan pengawasan dan mengevaluasi pelaksanaan sidang online ini. 


\section{Buku}

\section{DAFTAR PUSTAKA}

Hamzah, Andi. 2008, Hukum Acara Pidana Indonesia. Jakarta: Sinar Grafika. 2009, Hukum Acara Pidana, Jakarta: Sinar Grafika.

M.A., Aristo Pangaribuan, Arsa Mufti, dan Ichsan Zikry, 2017, Pengantar Hukum Acara Pidana Di Indonesia, Jakarta: Raja Grafindo.

Mulyadi, Lilik, 2012, Hukum Acara Pidana Indonesia: Suatu Tinjauan Khusus Terhadap Surat Dakwaan, Eksepsi,dan Putusan Pengadilan, Bandung: PT. Citra. Aditya Bakti.

Subekti, 2015, Hukum Pembuktian, Jakarta: Pradnya Paramita.

\section{Peraturan Perundang-Undangan}

Undang-Undang Republik Indonesia Nomor 8 Tahun 1981 tentang Hukum Acara Pidana atau Kitab Undang-Undang Hukum Acara Pidana (KUHAP).

Peraturan Mahkamah Agung Republik Indonesia Nomor 4 Tahun 2020 tentang Administrasi dan Persidangan Perkara Pidana di Pengadilan Secara Elektronik.

\section{Jurnal}

Anggi Astari Amelia Putri dan Dahlan Ali, (2020), Keabsahan Pembuktian Perkara Pidana Dalam Sidang yang Dilaksanakan Via Daring (Video Conference) Dalam Masa Pandemi Covid-19, Syiah Kuala Law Journal, Volume 4, Nomor 3, Desember 2020. 
Anggita Doramia Lumbanraja, (2020), Perkembangan Regulasi dan Pelaksanaan Persidangan Online di Indonesia dan Amerika Serikat Selama Pandemi Covid-19, Jurnal Crepido, Volume 02, Nomor 01, Juli 2020.

Dewi Rahmaningsih Nugroho dan S.Suteki, (2020), Membangun Budaya Hukum Persidangan Virtual (Studi Perkembangan Sidang Tindak Pidana via Telekonferensi), Jurnal Pembangunan Hukum Indonesia, Volume 2, Nomor 3, Juli 2020.

Dian Cahyaningrum, (2020), Persidangan Secara Elektronik Pada Masa Pandemi Covid-19, Jurnal Hukum, Volume XII, No.14/II/Puslit, Juli 2020.

Damayanti, Ruth Marina, (2014), Legalitas Keterangan Saksi Melalui Teleconference Sebagai Alat Bukti Dalam Perkara Pidana, Jurnal Program Pascasarjana Ilmu Hukum Universitas Muhammadiyah Surakarta, Volume 5, Nomor 1.

Hanafi dan Reza Aditya Pamuji, (2019), Urgensi Keterangan Ahli Sebagai Alat Bukti Berdasarkan Sistem Peradilan Pidana di Indonesi, Jurnal Al'Adl, Volume 10, Nomor 1, Januari 2019.

Rizky P.Karo, (2020), Peradilan Tindak Pidana Melalui Media Elektronik (Sidang Pidana Online) Saat Pandemi Covid-19 Perspektif Teori Keadilan Bermartabat: Tantangan Dan Rekomendasi, Jurnal Spektrum Hukum, Volume 17, Nomor 2, 2020.

RR. Dewi Anggraeni, (2020) Wabah Pandemi Covid-19, Urgensi Pelaksanaan Sidang Secara Elektronik, ADALAH :Buletin Hukum dan Keadilan, Volome 4, Nomor 1, 2020.

Wahyu Iswantoro, (2020), Persidangan Pidana Secara Online, Respon Cepat MA Hadapi Pandemi Covid-19, Selisik, Volume 6, Nomor 1, Juni 2020.

\section{Internet}

Achmad Nasrudin Yahya, 09 Juli 2020, "Menyoal Payung Hukum Persidangan Online”, Kompas.com, https://nasional.kompas.com/read/2020/07/09/07160431, diakses tanggal 09 Juli 2020. 
Hamidah Abdurrachman, "Legalitas Persidangan Online Dalam Sistem Peradilan Pidana Indonesia", Univeritas Bung Hatta, https://hukum.bunghatta.ac.id, diakses tanggal 15 Juli 2020.

Indriyanto Seno Adji, "Persidangan Online Adalah Quasi Court", BeritaHukum.com, http://m.beritahukum.com/detail_berita.php, diakses pada tanggal 29 Maret 2020. 